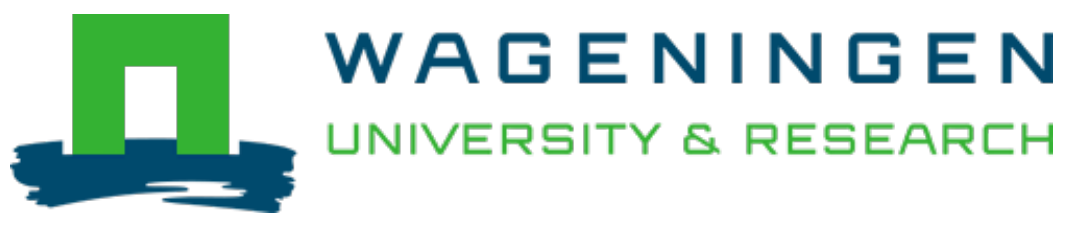

\title{
Towards green extraction methods from microalgae learning from the classics
}

Applied Microbiology and Biotechnology

Imbimbo, Paola; D'Elia, Luigi; Liberti, Davide; Olivieri, Giuseppe; Monti, Daria Maria

https://doi.org/10.1007/s00253-020-10839-x

This article is made publicly available in the institutional repository of Wageningen University and Research, under the terms of article $25 \mathrm{fa}$ of the Dutch Copyright Act, also known as the Amendment Taverne. This has been done with explicit consent by the author.

Article 25 fa states that the author of a short scientific work funded either wholly or partially by Dutch public funds is entitled to make that work publicly available for no consideration following a reasonable period of time after the work was first published, provided that clear reference is made to the source of the first publication of the work.

This publication is distributed under The Association of Universities in the Netherlands (VSNU) 'Article $25 \mathrm{fa}$ implementation' project. In this project research outputs of researchers employed by Dutch Universities that comply with the legal requirements of Article $25 \mathrm{fa}$ of the Dutch Copyright Act are distributed online and free of cost or other barriers in institutional repositories. Research outputs are distributed six months after their first online publication in the original published version and with proper attribution to the source of the original publication.

You are permitted to download and use the publication for personal purposes. All rights remain with the author(s) and / or copyright owner(s) of this work. Any use of the publication or parts of it other than authorised under article $25 \mathrm{fa}$ of the Dutch Copyright act is prohibited. Wageningen University \& Research and the author(s) of this publication shall not be held responsible or liable for any damages resulting from your (re)use of this publication.

For questions regarding the public availability of this article please contact openscience.library@wur.nl 


\title{
Towards green extraction methods from microalgae learning from the classics
}

\author{
Paola Imbimbo ${ }^{1} \cdot$ Luigi D'Elia $^{1} \cdot$ Davide Liberti ${ }^{~}$ Giuseppe Olivieri ${ }^{2,3} \cdot$ Daria Maria Monti $^{1}$ (I)
}

Received: 13 May 2020 / Revised: 29 July 2020 / Accepted: 14 August 2020 / Published online: 22 September 2020

(C) Springer-Verlag GmbH Germany, part of Springer Nature 2020

\begin{abstract}
Microalgae started receiving attention as producers of third generation of biofuel, but they are rich in many bioactive compounds. Indeed, they produce many molecules endowed with benefic effects on human health which are highly requested in the market. Thus, it would be important to fractionate algal biomass into its several high-value compounds: this represents the basis of the microalgal biorefinery approach. Usually, conventional extraction methods have been used to extract a single class of molecules, with many side effects on the environment and on human health. The development of a green downstream platform could help in obtaining different class of molecules with high purity along with low environmental impact. This review is focused on technical advances that have been performed, from classic methods to the newest and green ones. Indeed, it is fundamental to set up new procedures that do not affect the biological activity of the extracted molecules. A comparative analysis has been performed among the conventional methods and the new extraction techniques, i.e., switchable solvents and microwave-assisted and compressed fluid extractions.
\end{abstract}

Keywords Microalgae $\cdot$ Green chemistry $\cdot$ Switchable solvents $\cdot$ Microwave-assisted extraction $\cdot$ Compressed fluid extraction . Lipids

\section{Introduction}

In the last years, high-value bioproducts extracted from microalgae achieved a foothold in the market (Pulz and Gross 2004). Compared with conventional crops, microalgae are considered a fast and continuous source of polyunsaturated fatty acids, carotenoids, and proteins, which exert beneficial effects on humans (Vega-López et al. 2004; Zhang et al. 2014). Despite microalgae representing a huge alternative to

Giuseppe Olivieri

giuseppe.olivieri@wur.nl

Daria Maria Monti

mdmonti@unina.it

1 Department of Chemical Science, University of Naples Federico II, via Cinthia 4, 80126 Naples, Italy

2 Bioprocess Engineering Group, Wageningen University and Research, Droevendaalsesteeg 1, 6700AA Wageningen, the Netherlands

3 Department of Chemical, Materials and Industrial Engineering, University of Naples Federico II, Piazzale Tecchio 80, 80125 Napoli, Italy conventional feedstocks, three main drawbacks limit their use at large scale: (i) cultivation, (ii) harvesting, and (iii) downstream costs (Günerken et al. 2015; Zhang et al. 2016; Youn et al. 2017; Gifuni et al. 2019).

The main problems related to cultivation are (i) costs associated to the control of growth parameters, especially the temperature, and (ii) risks related to contaminations (Wang et al. 2013; Molina et al. 2019). To control them, microalgae are generally grown in photobioreactors (PBRs), which allow also obtaining high productivity yields and keeping the cultures axenic (Benedetti et al. 2004; Liu et al. 2019). However, as PBRs are very expensive for industrial applications, microalgae are grown in open pond systems (OPS), which are uncontrolled outdoor systems and do not allow a good productivity. OPS have pros (i-iii) and cons (iv-vi), such as (i) a low initial investment (Narala et al. 2016); (ii) a low power demand (Chen et al. 2013); (iii) low operating and maintenance costs (González-Delgado and Kafarov 2011); (iv) high contamination risk (Banerjee and Ramaswamy 2017); (v) requirement of large areas of land (Norsker et al. 2011); and (vi) high water demand to overcome the poor light utilization (Yin et al. 2020). Moreover, cultivations performed in these systems are strongly influenced by weather and 
environmental conditions. Indeed, controlling the growth parameters, such as temperature, $\mathrm{pH}$, and light intensity is still tricky and may affect the biomass productivity (Carvalho et al. 2006; Slegers et al. 2013; Koley et al. 2019). To face the contaminations, an optimization of highly selective environment is required. Among all the steps involved in the algal biomass production, the harvesting step represents the 20$30 \%$ of the overall costs (Rawat et al. 2011; Barros et al. 2015). Thus, the selection of the right technology to harvest the biomass is one of the key issues to make the microalgal exploitation cost-effective at large scale. The high costs are related to several factors, such as the high dilution of the culture that requires an intensive de-watering step; the density of the cells in the medium that is similar to the water density; and the negative charge of algal cells that implies an electrostatic repulsions among them, thus keeping cells in a stable disperse state (Zheng et al. 2012; Hu et al. 2014; Gayen et al. 2019). To date, the most common harvesting industrial procedures are centrifugation, flocculation, coagulation, and immobilization (Drexler and Yeh 2014; Fuad et al. 2018; Hidayah et al. 2019). These techniques present several disadvantages, not only for the elevated energy costs of each operation but also for the low separation efficiency (Danquah et al. 2009; $\mathrm{Xu}$ et al. 2010). For these reasons, the optimization of an efficient and economic harvesting procedure is still a challenge.

Another important issue to consider is the selection of the right extraction procedure to be employed. In fact, when extracting molecules from the biomass, one should choose a fully biocompatible buffer which will not alter the bioactivity of the extracted molecule. Currently, conventional extraction techniques involve the use of organic solvents, such as chloroform, acetone, methanol, and diethyl ether to be used in large amounts, for a long time and also the use of dry biomass as a starting material (Ghasemi Naghdi et al. 2016; Saini and Keum 2018; Zhang et al. 2019)

Recently, a new generation of extracting techniques, which do not require the involvement of toxic solvents, is being developed. Much effort has been done to set up green extraction procedures without using toxic solvents, thus minimizing environmental impact (Chemat et al. 2012; Armenta et al. 2019). Moreover, the new techniques allow to reduce the extraction time and to improve the extraction yields, without affecting the biological activity (Esquivel-Hernández et al. 2017; Dixon and Wilken 2018). To date, only few algae strains are considered suitable for the large-scale production (Brennan and Owende 2010; Kothari et al. 2017; De-Luca et al. 2019), such as Spirulina, Chlorella, Dunaliella salina, Aphanizomenon flosaquae, Haematococcus pluvialis, Crypthecodinium cohnii, and Shizochytrium (García et al. 2017).

One way to reduce the overall costs of microalgae cultivation on a large-scale production is the valorization of different microalgal biomass components (Lam et al. 2018; Chandra et al. 2019). In the last decades, the linear economy has given way to the circular economy, to promote a better use of resources by utilizing wastes and natural products as starting material, and to develop an integrated platform able to produce different bioproducts from biomasses (Bhalamurugan et al. 2018; Mathimani and Pugazhendhi 2019). In this context, microalgal biorefinery could be considered the most efficient and cost-effective approach to obtain different molecules, starting from the one endowed with the highest market value. This requires an appropriate selection of the extraction procedure to be employed. In this review, we will try to provide an overview on the different extraction techniques used for microalgae with a special focus on the improvements obtained.

\section{Organic-solvent extraction techniques}

The extraction step represents one of the main drawbacks in algae-based industries (Gifuni et al. 2019). Lipids and carotenoids are commonly recovered by using organic solvents, such as hexane, chloroform, acetone, methanol, and diethyl ether (Saini and Keum 2018). Conventional extractions usually require large amounts of organic solvent and long extraction times and they generally need dry biomass (Mansour et al. 2019; Sati et al. 2019). Moreover, a pretreatment step is often required before the extraction, thus increasing the overall costs (Alzate et al. 2012; Kadir et al. 2018). A brief description of the conventional methods, generally used to extract lipids, is reported, and the results obtained are summarized in Table 1.

\section{The Folch method}

The Folch method (Folch 1957) is one of the oldest methods employed for the extraction of lipids from microalgae and cyanobacteria. This procedure is fast and easy; however, it is less sensitive compared with the most recent procedures (Kumar et al. 2015). It requires chloroform and methanol as solvents, and it still represents one of the most used methods to estimate, spectrophotometrically, algal lipids. Banskota et al. (2019) extracted lipids from several microalgal strains. Extractions were performed starting from freeze-dried biomass using chloroform to methanol (2:1). They found that the method was able to extract from 30 to $40 \%$ (w/w of dry biomass) of lipids, with the exception of Nannochloropsis granulata in which the lipid content was $49.3 \pm 4.0 \%$ (w/w of dry biomass). Authors demonstrated also that the lipid content was directly related to ORAC values (Banskota et al. 2019). Schipper et al. (2019) studied novel microalgal strains isolated from extreme desert environments: Tetraselmis sp. 
Table 1 Different conventional extraction methods and their relative yields

\begin{tabular}{|c|c|c|c|c|c|}
\hline Microalgal species & Extraction method & Solvent & Biomass & Lipid yield (\%) & Reference \\
\hline N. oleoabundans & \multirow[t]{13}{*}{ Folch } & \multirow[t]{13}{*}{ Chloroform/methanol } & \multirow[t]{13}{*}{ Dry } & $31.8 \pm 6.7$ & (Banskota et al. 2019) \\
\hline B. braunii & & & & $41.1 \pm 5.5$ & (Banskota et al. 2019) \\
\hline P. tricornutum & & & & $44.8 \pm 3.6$ & (Banskota et al. 2019) \\
\hline N. granulata & & & & $49.3 \pm 4.0$ & (Banskota et al. 2019) \\
\hline C. sorokiniana & & & & $32.3 \pm 2.4$ & (Banskota et al. 2019) \\
\hline P. aerugineum & & & & $30.9 \pm 6.1$ & (Banskota et al. 2019) \\
\hline S. obliquus & & & & $40.5 \pm 7.8$ & (Banskota et al. 2019) \\
\hline Scenedesmus sp. & & & & $36.3 \pm 12.5$ & (Banskota et al. 2019) \\
\hline T. chui & & & & $32.1 \pm 5.5$ & (Banskota et al. 2019) \\
\hline T. subcordiformis QUCCCM51 & & & & $25.6 \pm 0.9$ & (Banskota et al. 2019) \\
\hline P. maculatum QUCCCM127 & & & & $28.0 \pm 2.0$ & (Banskota et al. 2019) \\
\hline N. oculata & & & & 24.4 & (Wei et al. 2014) \\
\hline T.subcordiformis & & & & 22.2 & (Wei et al. 2014) \\
\hline C. acidophila LAFIC-004 & \multirow[t]{5}{*}{ Bligh and Dyer } & \multirow[t]{4}{*}{ Chloroform $/$ methanol/water } & \multirow[t]{5}{*}{ Dry } & 54.6 & (Souza et al. 2017) \\
\hline I. galbana & & & & $25.3 \pm 0.2$ & (Bonfanti et al. 2018) \\
\hline C. sorokiniana & & & & 29.9 & (Rasouli et al. 2018) \\
\hline M. capsulatus & & & & 21.8 & (Rasouli et al. 2018) \\
\hline C. vulgaris & & Chloroform/methanol & & 10.4 & (Zullaikah et al. 2019) \\
\hline G. phlegrea & \multirow[t]{6}{*}{ Soxhlet } & \multirow[t]{2}{*}{ Chloroform/methanol } & \multirow[t]{6}{*}{ Dry } & $79 \pm 26$ & (Imbimbo et al. 2019) \\
\hline S. obliquus & & & & $17.4 \pm 0.4$ & (Wang et al. 2019) \\
\hline Chlorophyta sp. & & \multirow[t]{2}{*}{$n$-Hexane/ether } & & $18.3 \pm 0.4$ & (Yusuff 2019) \\
\hline C. gracilis & & & & 12.3 & (Kanda et al. 2020) \\
\hline P. carterae & & $n$-Hexane & & 7.5 & (Kanda et al. 2020) \\
\hline C. vulgaris & & Heptane & & $57.5 \pm 0.5$ & (Minyak et al. 2017) \\
\hline
\end{tabular}

and Picochlorum sp., characterized by their tolerance to high temperature and to high $\mathrm{CO}_{2}$ concentrations. The species were isolated, and lipid extraction showed that the two novel strains contained significant amounts of lipids, up to $25.6 \pm 0.9 \%$ and $28.0 \pm 2.0 \%$ (w/w of dry biomass), for Tetraselmis sp. and Picochlorum sp., respectively. The method is very reliable as different authors reported the same extraction yield for the same strain (Danquah et al. 2009; Wei et al. 2014).

\section{Bligh and Dyer}

The Bligh and Dyer method (Bligh and Dyer 1959) is similar to Folch method. It allows for the extraction of lipids from homogenized cells, generally using a mixture of chloroform/ methanol. It is a rapid and effective procedure, thus becoming a standard method for the lipid content determination in biological tissues (Iverson et al. 2001).

Souza and co-workers (Souza et al. 2017) studied the acidophilic microalga Chlamydomonas acidophila LAFIC-004 performing a lipid extraction by the Bligh and Dyer method and obtained $54.6 \%$ (w/w of dry biomass) of lipids. Bonfanti et al. (2018) performed lipid extraction starting from Isochrysis galbana, with a $25.3 \pm 0.2 \%$ (w/w of dry biomass) yield. Rasouli and co-workers (Rasouli et al. 2018) extracted about $30 \%$ of lipids from Chlorella sorokiniana, a value similar to that reported using the Folch method (Schipper et al. 2019), thus suggesting that all the methodologies are able to extract the same amount of lipids when the same strain and the same experimental procedure are followed.

\section{Soxhlet extraction}

Soxhlet extraction is a conventional procedure employed for the extraction of lipids and carotenoids. It is performed by using solvents at boiling temperature and ambient pressure, and even if it requires high amount of solvents and a long extraction time, it provides high yields and does not affect the bioactivity of the extracted molecules. We recently reported a Soxhlet extraction with chloroform to methanol $(2: 1)$ to obtain lipids from Galdieria phlegrea (Imbimbo et al. 2019). 
This procedure allowed obtaining a recovery of $79 \pm 26 \%$ (w/w of dry biomass) of lipids starting from the dried biomass (Imbimbo et al. 2019). Yusuff reported an oil extraction performed by Soxhlet from the green microalga Chlorophyta sp. The extraction was performed by using $n$-hexane to ether (4:1) mixture and allowed a yield of $18.3 \pm 0.4 \%$ (w/w of dry biomass) (Yusuff 2019). Kanda and colleagues used two different microalgae strains to extract lipids: Chaetoceros gracilis and Pleurochrysis carterae. Extractions were performed by Soxhlet using pure $n$-hexane. This technique allowed achieving yields of $12.3 \%$ (w/w of dry biomass) for C. gracilis and $7.5 \%$ (w/w of dry biomass) for P. carterae (Kanda et al. 2020).

\section{Green extraction techniques}

Recently, the demand for greener, safer, and more natural products that do not require the involvement of toxic solvent increased. The development of green extraction procedures to recover valuable compounds from natural sources represents a significant advance. These eco-friendly techniques allow obtaining bioactive products by reducing or completely replacing toxic solvents, thus minimizing the environmental impact, in agreement with several Green Chemistry principles (Capello et al. 2007; Anastas and Eghbali 2010; Jeevan Kumar et al. 2017). Moreover, a reduction in the extraction time and an improvement in the extraction yields have been obtained. Nevertheless, only few innovative techniques succeeded so far.

\section{Ionic liquids and switchable solvents}

Ionic liquids (ILs) are organic solution of salts that can melt at mild temperature $\left(<100^{\circ} \mathrm{C}\right)$. They are typically composed of a large number of inorganic or organic cations and are characterized by synthetic flexibility and thermal stability. Moreover, they are non-volatile and non-flammable (Vekariya 2017; Harris et al. 2018), being a good alternative to conventional solvents. They are generally employed for lipid extraction; however, to date, only limited papers are available in literature (Motlagh et al. 2019). One of the main drawbacks of ILs is the unrealistic application at industrial scale, due to their costs and the environmental impact (Zhang et al. 2008). Indeed, many ILs have been proved to be not harmful for humans, but their synthesis involves many steps that require expensive, toxic, and volatile reagents (Domínguez de María 2017; Harris et al. 2018; Singh and Savoy 2020). In recent years, a second generation of ILs has been developed: switchable solvents (SSs). First reported by Philipp Jessop et al. (2005), SSs are non-volatile liquids able to switch from hydrophobic to hydrophilic state and vice versa in response to external stimuli, such as temperature or $\mathrm{pH}$ variation and/or the addition or removal of a gas (i.e., $\mathrm{CO}_{2}$ ) (Al-Ameri and Al-Zuhair 2019; Do Yook et al. 2019). Theoretically, these SSs have many pros: (i) they allow performing cascade extractions of high-value molecules, (ii) it is possible to recover and reuse the solvent; thus, they are considered economically competitive and they require low energy consumption (iii); (iv) they are eco-friendly; (v) they are highly selective; and (vi) they enable extractions in a short time (Pollet et al. 2011; Jeevan Kumar et al. 2017; Clarke et al. 2018). For all these reasons, the second generation of SSs is considered green (Vanderveen et al. 2014; Jeevan Kumar et al. 2017). However, many cons have emerged with respect to solvent loss. This is mainly due to (i) the use of $\mathrm{CO}_{2}$ in the switching process; (ii) the impossibility to completely remove the solvent from the residual biomass after the process; and (iii) the release of the solvent in water. To improve SS properties, functional groups may be incorporated into the structure during the chemical synthesis, with increase in production costs (Clarke et al. 2018). Nowadays, primary, secondary, and tertiary amines are among the most SSs (Schuur et al. 2019). Table 2 reports a comparison between the lipid yield extraction by using SSs and conventional methods.

Research on SSs is quite recent. In 2018, Cicci et al. (2018) used N,N-dimethyl-cyclohexylamine (DMCHA) on the wet biomass of Scenedesmus dimorphus to extract lipids. The lipid yield was $35.6 \%$ (w/w of dry biomass), about 1.2 -fold more than the yield obtained by Gour and colleagues with a conventional method (Bligh and Dyer) (Gour et al. 2020). Nevertheless, the experimental procedure seemed to be able to extract similar amount of lipids independently from the strain. Indeed, the lipid yields obtained by Cicci et al. (2018) on Scenedesmus dimorphus can be compared with the lipid yield obtained by Samorì et al. (2013) on Tetraselmis suecica (31.9\%). Instead, Du et al. (2013) showed that Neyhylbutylamine (EBA) was able to extract lipids from Desmodesmus sp. with a yield of $16.8 \%$ (w/w of dry biomass), a value lower than that obtained by Samorì and colleagues who used DMCHA (29.2\%) (Samorì et al. 2013). Indeed, the yield was higher than that obtained by the Bligh and Dyer method (Du et al. 2013; Samorì et al. 2013). Probably, the tertiary amine DMCHA allows a better extraction of the lipid fraction from the biomass, as it is more hydrophobic than the secondary amine EBA. Afterwards, Du et al. (2018) showed that, starting from a stressed culture of Neochloris oleoabundans, EBA allowed to obtain an increase in the lipid yield, from 47.0 to $61.3 \%$ (w/w of dry biomass), only by increasing the number of extractions. In this case, authors found that EBA extracted about 4 times more lipids than the Bligh and Dyer method. It has to be noticed, however, that the switch back has not been reported in literature yet, so that the use of SSs is still far from being used in a biorefinery approach. 
Table 2 Yields obtained with switchable solvent method from different microalgae

\begin{tabular}{|c|c|c|c|c|c|c|}
\hline $\begin{array}{l}\text { Microalgal } \\
\text { species }\end{array}$ & Extraction method & Solvent & Biomass & Lipid yield (\%) & Fold increase & Reference \\
\hline $\begin{array}{l}\text { S. dimorphus } \\
\text { (UTEX 1237) }\end{array}$ & Switchable solvent & DMCHA & Wet & $35.6 \pm 1.9$ & 1.2 & (Cicci et al. 2018) \\
\hline S. dimorphus (Sd12) & Bligh and Dyer & Chloroform/methanol/water & Dry & 30.7 & & (Gour et al. 2020) \\
\hline \multirow[t]{2}{*}{ N. gaditana } & Switchable solvent & DMCHA & Wet & $57.9 \pm 1.3$ & 1.3 & (Samorì et al. 2013) \\
\hline & Bligh and Dyer & Chloroform/methanol/water & Dry & $45.1 \pm 0.9$ & & (Samorì et al. 2013) \\
\hline \multirow[t]{2}{*}{ T. suecica } & Switchable solvent & DMCHA & Wet & $31.9 \pm 1.5$ & 1.3 & (Samorì et al. 2013) \\
\hline & Bligh and Dyer & Chloroform/methanol/water & Dry & $25.4 \pm 2.6$ & & (Samorì et al. 2013) \\
\hline \multirow[t]{2}{*}{ D. communis } & Switchable solvent & DMCHA & Wet & $29.2 \pm 0.9$ & 1.6 & (Samorì et al. 2013) \\
\hline & Bligh and Dyer & Chloroform/methanol/water & Dry & $17.8 \pm 0.1$ & & (Samorì et al. 2013) \\
\hline \multirow[t]{2}{*}{ Desmodesmus sp. } & Switchable solvent & EBA & Wet & $16.8 \pm 0.5$ & 1.3 & (Du et al. 2013) \\
\hline & Bligh and Dyer & Chloroform/methanol/water & Dry & $12.8 \pm 0.6$ & & (Du et al. 2013) \\
\hline \multirow[t]{2}{*}{ N. oleoabundans } & Switchable solvent & EBA & Wet & 47.0 & 1 & (Du et al. 2017; Du et al. 2018) \\
\hline & Bligh and Dyer & Chloroform/methanol/water & Dry & 13.1 & & (Du et al. 2017; Du et al. 2018) \\
\hline \multirow[t]{6}{*}{ Chlorella sp. } & Switchable solvent & EBA & Wet & $12.3 \pm 3.2$ & $3.2 *$ & (Al-Ameri and Al-Zuhair 2019) \\
\hline & & DMCHA & & $133+0.4$ & $\begin{array}{l}1.3 * * \\
3.5 *\end{array}$ & (Al-Ameri and Al-Zuhair 2019) \\
\hline & & & & & $1.4 * *$ & \\
\hline & & Dipropylamine & & $7.0 \pm 1.3$ & & (Al-Ameri and Al-Zuhair 2019) \\
\hline & Conventional & {$[\mathrm{Bmim}][\mathrm{PF} 6]$} & Dry & $3.8 \pm 1.1$ & & (Al-Ameri and Al-Zuhair 2019) \\
\hline & & $n$-Hexane & & $9.4 \pm 0.7$ & & (Al-Ameri and Al-Zuhair 2019) \\
\hline
\end{tabular}

*With respect to [Bmim][PF6]

**With respect to $n$-hexane

\section{Microwave-assisted extraction}

Microwave-assisted extraction (MAE) involves the use of microwaves to heat up the solvent in contact with the cell thus allowing to extract pigments, lipids, and other bioactive molecules (Juin et al. 2015). The heating is caused by two phenomena: dipole rotation and ionic conduction, which may happen individually or simultaneously (Tatke and Jaiswal 2011). MAE is generally performed in closed systems to avoid heating dissipation. By this way, the heating mechanism is targeted and selective, thus reducing the extraction time and improving the final yield. However, the main limitation of this method is the high temperature required that might affect the bioactivity of the extracted molecules. A study from Mahfud's group indicated that MAE was able to increase by almost 10 times the lipid extraction yield in Spirulina platensis, with respect to Soxhlet (Kalsum et al. 2019), when $n$-hexane was used as solvent. These and other results are reported in Table 3, with a comparison with conventional methods.

In the extraction processes using microwave, the use of a mixture of solvents may result in an increase of the yield. As an example, the mixture $n$-hexane/methanol is a non-polar solvent able to solve oils from the matrix cells of microalgae. On the other hand, methanol allows microalgae to absorb more microwave energy with a consequent increase in microalgal disruption (Kalsum et al. 2019).

Krishnan and colleagues studied the importance of different ILs in the MAE extraction system on Chlorella vulgaris. Interestingly, they found that the extraction yield increased from 10.9 (Bligh and Dyer method) to $19.2 \%$ (w/w of dry biomass) when the 1-octyl-3-methylimidazolium acetate ([Omim] [OAc]) was used (Krishnan et al. 2020). In general, they found that the polarity of the ILs and the electronegativity of the anions used played an important role in the type of lipids extracted: the higher the hydrophobicity of the anion used, the higher the extraction of non-polar compounds.

Recently, Zghaibi et al. (2019) found that it was possible to use MAE to extract lipids from Nannochloropsis sp. by using only $10 \% \mathrm{NaCl}$ (6.9\% yield). In particular, the lipid extraction yield was similar with respect to Soxhlet extraction (4.5\%), and lower with respect to the Bligh and Dyer (18\%). However, MAE fully replaced the use of organic and harmful solvents, and, noteworthy, a better quality of lipids was obtained (polyunsaturated fatty acids and omega-3) (Zghaibi et al. 2019). It has to be considered that water, which as a highly polar solvent, can absorb microwave energy, and $\mathrm{NaCl}$ can improve the dielectric loss responsible for converting microwave energy into heat. The result is a higher efficiency in PUFA recovery. 
Table 3 Yields obtained with MAE method from different microalgae

\begin{tabular}{|c|c|c|c|c|c|c|c|}
\hline $\begin{array}{l}\text { Microalgal } \\
\text { species }\end{array}$ & $\begin{array}{l}\text { Extraction } \\
\text { method }\end{array}$ & Solvent & Biomass & $\begin{array}{l}\text { Operative } \\
\text { parameters }\end{array}$ & $\begin{array}{l}\text { Lipid yield } \\
(\%)\end{array}$ & $\begin{array}{l}\text { Fold } \\
\text { increase }\end{array}$ & Reference \\
\hline \multirow[t]{2}{*}{ S. platensis } & MAE & Methanol $/ n$-hexane & \multirow[t]{7}{*}{ Dry } & \multirow[t]{2}{*}{$600 \mathrm{~W} ; 40 \mathrm{~min}$} & 12.5 & \multirow[t]{2}{*}{9.6} & (Kalsum et al. 2019) \\
\hline & Soxhlet & n-Hexane & & & 1.3 & & (Kalsum et al. 2019) \\
\hline \multirow[t]{2}{*}{ C. vulgaris } & MAE & $\begin{array}{l}\text { Chloroform/methanol/water } \\
\text { [Omim] }[\text { OAc] } 2.5 \%\end{array}$ & & \multirow[t]{2}{*}{$700 \mathrm{~W} ; 10 \mathrm{~min}$} & 19.2 & \multirow[t]{2}{*}{1.8} & $\begin{array}{l}\text { (Krishnan et al. } \\
\text { 2020) }\end{array}$ \\
\hline & Bligh and Dyer & Chloroform/methanol/water & & & 10.9 & & $\begin{array}{l}\text { (Krishnan et al. } \\
\text { 2020) }\end{array}$ \\
\hline \multirow{3}{*}{$\begin{array}{l}\text { Nannochloropsis } \\
\quad \text { sp. }\end{array}$} & MAE & Water/sodium chloride $10 \%$ & & \multirow[t]{3}{*}{$800 \mathrm{~W} ; 30 \mathrm{~min}$} & 6.9 & \multirow{3}{*}{$\begin{array}{l}1.5^{*} \\
0.38 * *\end{array}$} & (Zghaibi et al. 2019) \\
\hline & Soxhlet & $n$-hexane & & & 4.5 & & (Zghaibi et al. 2019) \\
\hline & Bligh and Dyer & Chloroform/methanol/water & & & 18 & & (Zghaibi et al. 2019) \\
\hline
\end{tabular}

*With respect to Soxhlet

**With respect to Bligh and Dyer

\section{Compressed fluid extractions}

Compressed fluid extractions are considered valuable green alternatives to conventional extractions. They include subcritical water extraction (SWE), pressurized liquid extraction (PLE), and supercritical fluid extraction (SFE). Solvents involved in PLE and SWE are maintained at a temperature above the boiling point and at a pressure high enough to keep fluids in their liquid states (Ramos et al. 2002). On the other hand, SFE operates at temperature and pressure above the critical point of the solvent selected (Herrero et al. 2013). These conditions allow for the increase of diffusivity of the solvent, thus improving the penetration of the solvent into the matrix (Phelps et al. 1996). Besides the differences between these techniques, they all require minimum amount of GRAS solvents to perform selective extraction of bioactive compounds, without affecting the bioactivity or the chemical structure (Herrero and Ibañez 2018). Unfortunately, they are still not diffused due to the high investment costs (Herrero and Ibañez 2018). So far, $\mathrm{CO}_{2}$ is the most used solvent, especially in supercritical extractions (Goto et al. 2015). $\mathrm{CO}_{2}$ is an economic, non-harmful, non-flammable, and recyclable solvent. Due to its thermodynamic properties, at supercritical conditions, $\mathrm{CO}_{2}$ shows a high diffusivity and a high density that allow a better penetration into the matrix (Goto et al. 2015; Molino et al. 2020). However, supercritical $\mathrm{CO}_{2}\left(\mathrm{ScCO}_{2}\right)$ is limited to the extraction of non-polar or low polar compounds (Gilbert-López et al. 2015; Gallego et al. 2019). To overcome this problem, a low amount of co-solvent (e.g., ethanol) can be used to increase the $\mathrm{CO}_{2}$ polarity.

According to this, Nobre and co-workers performed a lipid extraction starting from the dried biomass of Nannochloropsis sp. (NANNO-2) by using $\mathrm{ScCO}_{2}$ in the presence and in the absence of a co-solvent (20\% ethanol). Authors found that $\mathrm{ScCO}_{2}$ combined with ethanol was able to increase lipid yield, as $45 \%$ (w/w of dry biomass) of lipid yield was obtained with respect to $32 \%$ yield ( $\mathrm{w} / \mathrm{w}$ of dry biomass), in the absence of co-entrainer (Nobre et al. 2013). Moreover, Zullaikah et al. (2019) performed a lipid extraction from the wet raw biomass of Chlorella vulgaris by SWE. Besides the co-solvent, time and temperature may also affect the extraction yields. For this reason, experiments were performed in the presence or absence of co-solvents, at different temperatures and different time. In particular, chloroform, methanol, ethanol, ethyl acetate, and $n$-hexane were tested as co-solvents. Extractions were performed at $160{ }^{\circ} \mathrm{C}, 80 \mathrm{bar}$, at $160{ }^{\circ} \mathrm{C}, 180^{\circ} \mathrm{C}$ and $200^{\circ} \mathrm{C}$, for $15 \mathrm{~min}, 30 \mathrm{~min}, 1 \mathrm{~h}, 3 \mathrm{~h}$, and $5 \mathrm{~h}$. All the results were then compared with conventional Bligh and Dyer extraction. The study revealed that SWE performed at $200{ }^{\circ} \mathrm{C}$, 80 bar for $30 \mathrm{~min}$, using ethyl acetate as co-solvent, gave the highest lipid yield $(65.94 \%$, w/w of dry biomass), while conventional chloroform/methanol extraction allowed for the obtaining of a lipid yield of $10.43 \%$ (w/w of dry biomass). Altenhofen da Silva and co-workers evaluated the effect of supercritical carbon dioxide $\left(\mathrm{ScCO}_{2}\right)$ on freeze-dried biomass of Desmodesmus subspicatus. Extractions were performed comparing two different pressures (20 and $30 \mathrm{MPa}$, that correspond to 200 and 300 bar, respectively) at $60{ }^{\circ} \mathrm{C}$. Authors found out that a direct correlation was observed with pressure and lipid yield, as, at $30 \mathrm{MPa}, 45 \%$ of lipids were recovered, a value which is almost the double of that obtained at $20 \mathrm{MPa}$ or with Soxhlet (23\% at and 20\%, respectively) (Altenhofen et al. 2016).

Zimmerer et al. (2019) employed Phaeodactylum tricornutum dry biomass for lipid extraction. Cells were disrupted by ultrasonication prior the extraction with $\mathrm{ScCO}_{2}$. Among the different pressures and temperatures tested, $90{ }^{\circ} \mathrm{C}$ and 621 bar were found to be the best conditions, as a $25 \%$ yield was obtained (w/w of dry biomass). As a reference, lipids were extracted by Folch method, using a mixture of 
water, methanol, and chloroform. The lipid yield obtained by the conventional method was $28 \%$ (w/w of dry biomass). He and co-workers set up a process to obtain lipids from Isochrysis sp. dried biomass. Lipids were extracted by $3 \mathrm{cy}-$ cles of 5 min each of PLE, at $103 \mathrm{bar}, 80{ }^{\circ} \mathrm{C}$, using two different solvents: $n$-hexane and ethanol. Soxhlet extraction (with hexane) and Folch method (with a mixture of chloroform $/$ methanol/water) were performed to compare the extraction yields. PLE with $n$-hexane gave a higher yield (34.42\%) when compared with Soxhlet extraction performed with the same solvent (about 19\% yield). However, PLE performed by using ethanol improved the process, as the lipid yield was $38.94 \%$ (w/w of dry biomass) (He et al. 2019).

We recently reported a process intensification to obtain three different high-value molecules in a biorefinery approach (Imbimbo et al. 2019). In particular, we improved lipid extraction as the third step of the cascade process. The extraction was performed using pure $\mathrm{CO}_{2}$ as solvent, at 350 bar, $60{ }^{\circ} \mathrm{C}$ for $100 \mathrm{~min}$ starting from the wet biomass of Galdieria phlegrea. The yield was then compared with the one obtained by a conventional extraction performed with $0.37 \% \mathrm{NaCl}$ in chloroform/methanol (2:1) on dry biomass. SFE allowed for the obtaining of $18.4 \%$ yield ( $\mathrm{w} / \mathrm{w}$ of dry biomass), in comparison with $11 \%$ yield (w/w of dry biomass) obtained by the conventional extraction method (Imbimbo et al. 2020). All the extraction yields are reported in Table 4.

\section{Conclusions}

Microalgae represent a natural source of bioactive compounds to be used in pharmaceutical, nutraceutical, cosmetic, and food sectors. In particular, many hydrophobic molecules endowed with special biological activity can be extracted from microalgae and used. Of course, during extraction, many parameters have to be considered. An ideal extraction method should allow to operate at low costs and to preserve both the original characteristics of the isolated molecule and of the residual biomass. Green extraction techniques seem to combine environmentally friendly and cost-effective extractions. Most of them are economically and environmentally sustainable and non-toxic and can increase the selectivity and

Table 4 Yields obtained with compressed fluid extraction methods from different microalgae

\begin{tabular}{|c|c|c|c|c|c|c|}
\hline Microalgal species & $\begin{array}{l}\text { Extraction } \\
\text { method }\end{array}$ & Solvent & Biomass & $\begin{array}{l}\text { Lipid yield } \\
(\%)\end{array}$ & $\begin{array}{l}\text { Fold } \\
\text { increase }\end{array}$ & Reference \\
\hline \multirow{5}{*}{$\begin{array}{l}\text { Nannochloropsis sp. } \\
\text { (NANNO-2) }\end{array}$} & \multirow[t]{2}{*}{ SFE } & $\mathrm{CO}_{2}$ & \multirow[t]{5}{*}{ Dry } & 34 & \multirow[t]{5}{*}{$1.3 *$} & (Nobre et al. 2013) \\
\hline & & $\mathrm{CO}_{2}+20 \%$ ethanol & & 45 & & (Nobre et al. 2013) \\
\hline & \multirow[t]{2}{*}{ Soxhlet } & $n$-Hexane & & 40.7 & & (Nobre et al. 2013) \\
\hline & & Ethanol & & 50.6 & & (Nobre et al. 2013) \\
\hline & Bligh and Dyer & Chloroform/methanol/water & & 25.3 & & (Nobre et al. 2013) \\
\hline \multirow[t]{2}{*}{ G. phlegrea } & SFE & $\mathrm{CO}_{2}$ & Wet & $18.4 \pm 0.5$ & \multirow[t]{2}{*}{1.7} & (Imbimbo et al. 2020) \\
\hline & Conventional & $\begin{array}{l}\text { Chloroform/methanol/sodium } \\
\text { chloride }\end{array}$ & Dry & $11 \pm 0.3$ & & (Imbimbo et al. 2020) \\
\hline \multirow[t]{2}{*}{ C. vulgaris } & SWE & Water/ethyl acetate & Wet & 65.9 & \multirow[t]{2}{*}{6.3} & (Zullaikah et al. 2019) \\
\hline & Bligh and Dyer & Chloroform/methanol & Dry & 10.4 & & (Zullaikah et al. 2019) \\
\hline \multirow[t]{2}{*}{ D. subspicatus } & SFE & $n$-Hexane & \multirow[t]{2}{*}{ Dry } & 45 & \multirow[t]{2}{*}{2.3} & $\begin{array}{l}\text { (Altenhofen et al. } \\
\text { 2016) }\end{array}$ \\
\hline & Soxhlet & Chloroform $/$ methanol $/$ water & & 20 & & $\begin{array}{l}\text { (Altenhofen et al. } \\
\text { 2016) }\end{array}$ \\
\hline \multirow[t]{2}{*}{ P. tricornutum } & SFE & $\mathrm{CO}_{2}$ & \multirow[t]{2}{*}{ Dry } & 25 & \multirow[t]{2}{*}{0.9} & (Zimmerer et al. 2019) \\
\hline & Folch & Chloroform/methanol/water & & 28 & & (Zimmerer et al. 2019) \\
\hline \multirow[t]{4}{*}{ Isochrysis $\mathrm{sp}}$. & PLE & $n$-Hexane & \multirow[t]{4}{*}{ Dry } & 34.41 & \multirow{4}{*}{$\begin{array}{l}1.4 * * \\
1.8 * * * \\
1.5 * * \\
2 * * *\end{array}$} & (He et al. 2019) \\
\hline & PLE & Ethanol & & 38.94 & & (He et al. 2019) \\
\hline & Folch & Chloroform $/$ methanol/water & & 25.36 & & (He et al. 2019) \\
\hline & Soxhlet & $n$-Hexane & & 19 & & (He et al. 2019) \\
\hline
\end{tabular}

*With respect to SFE in absence of co-solvent

**With respect to Folch

$* * *$ With respect to Soxhlet 
extraction efficiency (Domínguez de María 2017; Häckl and Kunz 2018; Singh and Savoy 2020). However, all of them have pros and cons with respect to the industrial benchmark of extraction with organic solvent.

In particular, MAE is a green technique used to recover different thermo-stable molecules. Of course, this can be a problem in the case of thermolabile molecules as the experimental conditions used may affect the physical-chemical properties of the isolated molecules. Furthermore, the efficiency of the extraction is often lower with respect to organic solvents.

Compressed fluid extractions can represent an excellent alternative to recover thermolabile molecules. The major advantage resides in the possibility to recover and recycle the solvent. Furthermore, the solvent polarity can be tuned by combining the neutral $\mathrm{CO}_{2}$ with polar co-solvents, such as ethanol or isopropanol. The major limitation of compressed fluid extractions is represented by its initial investment costs. Lab-scale tests seem efficient when achieving $>300$-bar pressure, which is often economically unfeasible at industrial scale. In case of switchable solvents, solvent separation and recycle are the main advantage. Furthermore, the tunability of the polarity allows these solvents to extract both hydrophobic and hydrophilic molecules only by switching a chemicalphysical factor. What is still a pending point for SSs is their effect on the residual biomass after the extraction. Unfortunately, there is still much effort to be done to use these solvents, as no evidence of their extraction abilities have been reported after the switch.

Generally speaking, one should keep in mind that microalgae can be used as an excellent source of bioactive molecules provided that a biorefinery approach has to be used. Thus, microalgae costs have to be paid by obtaining more than a class of molecules, starting from the one with the highest market value. So, if the biorefinery approach includes downstream processes able to fulfill the requirements of Green Chemistry, it will end up with a new and sustainable process. With respect to green extraction techniques of lipids and pigments, less is known on two important aspects: the residual amount of solvent in the biomass and, mainly, the effect of the extraction on the other molecules in the leftover spent biomass. This review provides a step further in the extraction knowledge that can help to valorize microalgae biomass by using innovative extraction techniques, which comply with the Green Chemistry principles.

\section{References}

Al-Ameri M, Al-Zuhair S (2019) Using switchable solvents for enhanced, simultaneous microalgae oil extraction-reaction for biodiesel production. Biochem Eng J 141:217-224. https://doi.org/10.1016/ j.bej.2018.10.017

Altenhofen M, Barbosa H, Brito C, Arjonilla F, Bastos G, Guenter T (2016) Heterotrophic growth of green microalgae Desmodesmus subspicatus in ethanol distillation wastewater (vinasse) and lipid extraction with supercritical $\mathrm{CO}_{2}$. J Chem Technol Biotechnol 92: 573-579. https://doi.org/10.1002/jctb.5035

Alzate ME, Muñoz R, Rogalla F, Fdz-Polanco F, Pérez-Elvira SI (2012) Biochemical methane potential of microalgae: influence of substrate to inoculum ratio, biomass concentration and pretreatment. Bioresour Technol 123:488-494. https://doi.org/10.1016/j. biortech.2012.06.113

Anastas P, Eghbali N (2010) Green chemistry: principles and practice. Chem Soc Rev 39:301-312. https://doi.org/10.1039/b918763b

Armenta S, Garrigues S, Esteve-Turrillas FA, de la Guardia M (2019) Green extraction techniques in green analytical chemistry. TrAC Trends Anal Chem 116:248-253. https://doi.org/10.1016/j.trac. 2019.03.016

Banerjee S, Ramaswamy S (2017) Dynamic process model and economic analysis of microalgae cultivation in open raceway ponds. Algal Res 26:330-340. https://doi.org/10.1016/j.algal.2017.08.011

Banskota AH, Sperker S, Stefanova R, McGinn PJ, O’Leary SJB (2019) Antioxidant properties and lipid composition of selected microalgae. J Appl Phycol 31:309-318. https://doi.org/10.1007/s10811-0181523-1

Barros AI, Gonçalves AL, Simões M, Pires JCM (2015) Harvesting techniques applied to microalgae: a review. Renew Sust Energ Rev 41: 1489-1500. https://doi.org/10.1016/j.rser.2014.09.037

Benedetti S, Benvenuti F, Pagliarani S, Francogli S, Scoglio S, Canestrari F (2004) Antioxidant properties of a novel phycocyanin extract from the blue-green alga Aphanizomenon flos-aquae. Life Sci 75:23532362. https://doi.org/10.1016/j.lfs.2004.06.004

Bhalamurugan GL, Valerie O, Mark L (2018) Valuable bioproducts obtained from microalgal biomass and their commercial applications: a review. Environ Eng Res 23:229-241. https://doi.org/10.4491/eer. 2017.220

Bligh EG, Dyer WJ (1959) A rapid method of total lipid extraction and purification. Can J Biochem Physiol 37:911-917. https://doi.org/10. 1139/y59-099

Bonfanti C, Cardoso C, Afonso C, Matos J, Garcia T, Tanni S, Bandarra NM (2018) Potential of microalga Isochrysis galbana: bioactivity and bioaccessibility. Algal Res 29:242-248. https://doi.org/10. 1016/j.algal.2017.11.035

Brennan L, Owende P (2010) Biofuels from microalgae - a review of technologies for production, processing, and extractions of biofuels and co-products. Renew Sust Energ Rev 14:557-577. https://doi. org/10.1016/j.rser.2009.10.009

Capello C, Fischer U, Hungerbühler K (2007) What is a green solvent? A comprehensive framework for the environmental assessment of solvents. Green Chem 9:927-934. https://doi.org/10.1039/b617536h

Carvalho AP, Meireles A, Malcata FX (2006) Microalgal reactors: a review of enclosed system designs and performances. Biotechnol Prog 22:1490-1506. https://doi.org/10.1021/bp060065r

Chandra R, Iqbal MN, Vishal G, Lee H, Nagra S (2019) Bioresource technology algal biorefinery: a sustainable approach to valorize algal-based biomass towards multiple product recovery. 278:346359. https://doi.org/10.1016/j.biortech.2019.01.104

Chemat F, Vian MA, Cravotto G (2012) Green extraction of natural products: concept and principles. Int J Mol Sci 13:8615-8627. https://doi.org/10.3390/ijms13078615

Chen Y, Wang J, Zhang W, Chen L, Gao L, Liu T (2013) Forced light/ dark circulation operation of open pond for microalgae cultivation. Biomass Bioenergy 56:464-470. https://doi.org/10.1016/j. biombioe.2013.05.034 
Cicci A, Sed G, Jessop PG, Bravi M (2018) Circular extraction: an innovative use of switchable solvents for the biomass biorefinery. Green Chem 20:3908-3911. https://doi.org/10.1039/c8gc01731j

Clarke CJ, Tu WC, Levers O, Bröhl A, Hallett JP (2018) Green and sustainable solvents in chemical processes. Chem Rev 118:747800. https://doi.org/10.1021/acs.chemrev.7b00571

Danquah MK, Gladman B, Moheimani N, Forde GM (2009) Microalgal growth characteristics and subsequent influence on dewatering efficiency. Chem Eng J 151:73-78. https://doi.org/10.1016/j.cej.2009. 01.047

De-Luca R, Bezzo F, Béchet Q, Bernard O (2019) Meteorological databased optimal control strategy for microalgae cultivation in open pond systems. Complexity 2019:1-12. https://doi.org/10.1155/ 2019/4363895

Dixon C, Wilken LR (2018) Green microalgae biomolecule separations and recovery. Bioresour Bioprocess 5. https://doi.org/10.1186/ s40643-018-0199-3

Do Yook S, Kim J, Woo HM, Um Y, Lee SM (2019) Efficient lipid extraction from the oleaginous yeast Yarrowia lipolytica using switchable solvents. Renew Energy 132:61-67. https://doi.org/10. 1016/j.renene.2018.07.129

Domínguez de María P (2017) Chapter 6-ionic liquids, switchable solvents, and eutectic mixtures. In: Pena-Pereira F, Tobiszewski MBTTA of GS in SP (eds) The application of green solvents in separation processes. Elsevier, pp 139-154. https://doi.org/10.1016/B978-012-805297-6.00006-1

Drexler ILC, Yeh DH (2014) Membrane applications for microalgae cultivation and harvesting: a review. Rev Environ Sci Biotechnol 13:487-504. https://doi.org/10.1007/s11157-014-9350-6

Du Y, Schuur B, Samorì C, Tagliavini E, Brilman DWF (2013) Secondary amines as switchable solvents for lipid extraction from non-broken microalgae. Bioresour Technol 149:253-260. https:// doi.org/10.1016/j.biortech.2013.09.039

Du Y, Schuur B, Brilman DWF (2017) Maximizing lipid yield in Neochloris oleoabundans algae extraction by stressing and using multiple extraction stages with $\mathrm{N}$-ethylbutylamine as switchable solvent. Ind Eng Chem Res 56:8073-8080. https://doi.org/10. 1021/acs.iecr.7b01032

Du Y, Schuur B, Kersten SRA, Brilman DWF(W) (2018) Multistage wet lipid extraction from fresh water stressed Neochloris oleoabundans slurry-Experiments and modelling. Algal Res 31:21-30. https://doi. org/10.1016/j.algal.2018.01.001

Esquivel-Hernández DA, Ibarra-Garza IP, Rodríguez-Rodríguez J, Cuéllar-Bermúdez SP, Rostro-Alanis M d J, Alemán-Nava GS, García-Pérez JS, Parra-Saldívar R (2017) Green extraction technologies for high-value metabolites from algae: a review. Biofuels Bioprod Biorefin 11:215-231. https://doi.org/10.1002/bbb.1735

Folch J (1957) A simple method for the isolation and purification of total lipids from animal tissues. J Biol Chem 266:497-509

Fuad N, Omar R, Kamarudin S, Harun R, Idris A, Wan WA (2018) Mass harvesting of marine microalgae using different techniques. Food Bioprod Process 112:169-184. https://doi.org/10.1016/j.fbp.2018. 10.006

Gallego R, Bueno M, Herrero M (2019) Sub- and supercritical fluid extraction of bioactive compounds from plants, food-by-products, seaweeds and microalgae-an update. TrAC - Trends Anal Chem 116:198-213. https://doi.org/10.1016/j.trac.2019.04.030

García JL, de Vicente M, Galán B (2017) Microalgae, old sustainable food and fashion nutraceuticals. Microb Biotechnol 10:1017-1024. https://doi.org/10.1111/1751-7915.12800

Gayen K, Bhowmick TK, Maity SK (Eds.) (2019) Sustainable downstream processing of microalgae for industrial application. CRC Press, Boca Raton

Ghasemi Naghdi F, González González LM, Chan W, Schenk PM (2016) Minireview progress on lipid extraction from wet algal biomass for biodiesel production. Microb Biotechnol 9:718-726. https://doi.org/ 10.1111/1751-7915.12360

Gifuni I, Pollio A, Safi C, Marzocchella A, Olivieri G (2019) Current bottlenecks and challenges of the microalgal biorefinery. Trends Biotechnol 37:242-252. https://doi.org/10.1016/j.tibtech.2018.09. 006

Gilbert-López B, Mendiola JA, Fontecha J, Van Den Broek LAM, Sijtsma L, Cifuentes A, Herrero M, Ibáñez E (2015) Downstream processing of Isochrysis galbana: a step towards microalgal biorefinery. Green Chem 17:4599-4609. https://doi.org/10.1039/ $\mathrm{c} 5 \mathrm{gc} 01256 \mathrm{~b}$

González-Delgado Á-D, Kafarov V (2011) Biorefinery: issues. CT\&F Ciencia, Tecnol y Futur 4(4):5-22

Goto M, Kanda H, Wahyudiono MS (2015) Extraction of carotenoids and lipids from algae by supercritical $\mathrm{CO}_{2}$ and subcritical dimethyl ether. J Supercrit Fluids 96:245-251. https://doi.org/10.1016/j.supflu. 2014.10.003

Gour RS, Garlapati VK, Kant A (2020) Effect of salinity stress on lipid accumulation in Scenedesmus sp. and Chlorella sp.: feasibility of stepwise culturing. Curr Microbiol. https://doi.org/10.1007/s00284019-01860-z

Günerken E, D’Hondt E, Eppink MHM, Garcia-Gonzalez L, Elst K, Wijffels RH (2015) Cell disruption for microalgae biorefineries. Biotechnol Adv 33(2):243-260. https://doi.org/10. 1016/j.biotechadv.2015.01.008

Häckl K, Kunz W (2018) Some aspects of green solvents. Comptes Rendus Chim 21:572-580. https://doi.org/10.1016/j.crci.2018.03. 010

Harris J, Viner K, Champagne P, Jessop PG (2018) Advances in microalgal lipid extraction for biofuel production: a review. Biofuels, Bioprod. Biorefining 12(6):1118-1135

He Y, Huang Z, Zhong C, Guo Z, Chen B (2019) Bioresource technology pressurized liquid extraction with ethanol as a green and efficient technology to lipid extraction of Isochrysis biomass. Bioresour Technol 293:122049. https://doi.org/10.1016/j.biortech.2019. 122049

Herrero M, Ibañez E (2018) Green extraction processes, biorefineries and sustainability: recovery of high added-value products from natural sources. J Supercrit Fluids 134:252-259. https://doi.org/10.1016/j. supflu.2017.12.002

Herrero M, Castro-Puyana M, Mendiola JA, Ibañez E (2013) Compressed fluids for the extraction of bioactive compounds. TrAC Trends Anal Chem 43:67-83. https://doi.org/10.1016/j.trac. 2012.12.008

Hidayah N, Yasin M, Shafei NI, Rushan NH, Raihana N, Sepian A, Said FM (2019) ScienceDirect the effect of microalgae harvesting on lipid for biodiesel production. Mater Today Proc 19:1582-1590. https://doi.org/10.1016/j.matpr.2019.11.186

Hu Y, Guo C, Wang F, Wang S, Pan F, Liu C (2014) Improvement of microalgae harvesting by magnetic nanocomposites coated with polyethylenimine. Chem Eng J 242:341-347. https://doi.org/10. 1016/j.cej.2013.12.066

Imbimbo P, Romanucci V, Pollio A, Fontanarosa C, Amoresano A, Zarrelli A, Olivieri G, Monti DM (2019) A cascade extraction of active phycocyanin and fatty acids from Galdieria phlegrea. Appl Microbiol Biotechnol 103:9455-9464. https://doi.org/10.1007/ s00253-019-10154-0

Imbimbo P, Bueno M, D’Elia L, Pollio A, Ibañez E, Olivieri G, Monti DM (2020) Green compressed fluid technologies to extract antioxidants and lipids from Galdieria phlegrea in a biorefinery approach. ACS Sustain Chem Eng 8:2939-2947. https://doi.org/10.1021/ acssuschemeng.9b07505

Iverson SJ, Lang SLC, Cooper MH (2001) Comparison of the bligh and dyer and folch methods for total lipid determination in a broad range of marine tissue. Lipids 36:1283-1287. https://doi.org/10.1007/ s11745-001-0843-0 
Jeevan Kumar SP, Vijay Kumar G, Dash A, Scholz P, Banerjee R (2017) Sustainable green solvents and techniques for lipid extraction from microalgae: a review. Algal Res 21:138-147. https://doi.org/10. 1016/j.algal.2016.11.014

Jessop PG, Heldebrant DJ, Li X, Eckert CA, Liotta CL (2005) Reversible nonpolar-to-polar solvent. Green Chem 436:1101-1102. https://doi. org/10.1038/nature4361101a

Juin C, Chérouvrier JR, Thiéry V, Gagez AL, Bérard JB, Joguet N, Kaas R, Cadoret JP, Picot L (2015) Microwave-assisted extraction of phycobiliproteins from Porphyridium purpureum. Appl Biochem Biotechnol 175:1-15. https://doi.org/10.1007/s12010-014-1250-2

Kadir WNA, Lam MK, Uemura Y, Lim JW, Lee KT (2018) Harvesting and pre-treatment of microalgae cultivated in wastewater for biodiesel production: a review. Energy Convers Manag 171:1416-1429. https://doi.org/10.1016/j.enconman.2018.06.074

Kalsum U, Kusuma HS, Roesyadi A, Mahfud M (2019) Lipid extraction from Spirulina platensis using microwave for biodiesel production. Korean Chem Eng Res 57:301-304. https://doi.org/10.9713/kcer. 2019.57.2.301

Kanda H, Hoshino R, Murakami K, Wahyudiono ZQ, Goto M (2020) Lipid extraction from microalgae covered with biomineralized cell walls using liquefied dimethyl ether. Fuel 262:116590. https://doi. org/10.1016/j.fuel.2019.116590

Koley S, Mathimani T, Bagchi SK, Sonkar S, Mallick N (2019) Microalgal biodiesel production at outdoor open and polyhouse raceway pond cultivations: a case study with Scenedesmus accuminatus using low-cost farm fertilizer medium. Biomass Bioenergy 120:156-165. https://doi.org/10.1016/j.biombioe.2018. 11.002

Kothari R, Pandey A, Ahmad S, Kumar A, Pathak VV, Tyagi VV (2017) Microalgal cultivation for value-added products: a critical enviroeconomical assessment. 3 Biotech 7:243

Krishnan S, Ghani NA, Aminuddin NF, Quraishi KS, Azman NS, Cravotto G, Leveque JM (2020) Microwave-assisted lipid extraction from Chlorella vulgaris in water with $0.5 \%-2.5 \%$ of imidazolium based ionic liquid as additive. Renew Energy 149:244-252. https:// doi.org/10.1016/j.renene.2019.12.063

Kumar RR, Rao PH, Arumugam M (2015) Lipid extraction methods from microalgae: a comprehensive review. 2:1-9. https://doi.org/ 10.3389/fenrg.2014.00061

Lam GP, Vermuë MH, Eppink MHM, Wijffels RH, Van Den Berg C (2018) Multi-product microalgae biorefineries: from concept towards reality. Trends Biotechnol 36:216-227. https://doi.org/10. 1016/j.tibtech.2017.10.011

Liu W, Chen Y, Wang J, Liu T (2019) Biomass productivity of Scenedesmus dimorphus (Chlorophyceae) was improved by using an open pond-photobioreactor hybrid system. Eur J Phycol 54:127134. https://doi.org/10.1080/09670262.2018.1519601

Mansour EA, Abo El-Enin SA, Hamouda AS, Mahmoud HM (2019) Efficacy of extraction techniques and solvent polarity on lipid recovery from domestic wastewater microalgae. Environ Nanotechnol Monit Manag 12:100271. https://doi.org/10.1016/j.enmm.2019. 100271

Mathimani T, Pugazhendhi A (2019) Utilization of algae for biofuel, bioproducts and bio-remediation. Biocatal Agric Biotechnol 17:326330. https://doi.org/10.1016/j.bcab.2018.12.007

Minyak P, Daripada A, Air M, Chlorella T (2017) Algae oil extraction from freshwater microalgae Chlorella vulgaris. Malaysian J Anal Sci 21:735-744. https://doi.org/10.17576/mjas-2017-2103-23

Molina D, de Carvalho JC, Júnior AIM, Faulds C, Bertrand E, Soccol CR (2019) Biological contamination and its chemical control in microalgal mass cultures. Appl Microbiol Biotechnol 103:93459358. https://doi.org/10.1007/s00253-019-10193-7

Molino A, Mehariya S, Di Sanzo G, Larocca V, Martino M, Leone GP, Marino T, Chianese S, Balducchi R, Musmarra D (2020) Recent developments in supercritical fluid extraction of bioactive compounds from microalgae: role of key parameters, technological achievements and challenges. J CO2 Util 36:196-209. https://doi. org/10.1016/j.jcou.2019.11.014

Motlagh SR, Harun R, Biak DRA, Hussain SA, Ghani WAWAK, Khezri R, Wilfred CD, Elgharbawy AAM (2019) Screening of suitable ionic liquids as green solvents for extraction of eicosapentaenoic acid (EPA) from microalgae biomass using COSMO-RS model. Molecules 24:713. https://doi.org/10.3390/molecules24040713

Narala RR, Garg S, Sharma KK, Thomas-Hall SR, Deme M, Li Y, Schenk PM (2016) Comparison of microalgae cultivation in photobioreactor, open raceway pond, and a two-stage hybrid system. Front Energy Res 4:1-10. https://doi.org/10.3389/fenrg.2016. 00029

Nobre BP, Villalobos F, Barragán BE, Oliveira AC, Batista AP, Marques PASS, Mendes RL, Sovová H, Palavra AF, Gouveia L (2013) A biorefinery from Nannochloropsis sp. microalga-extraction of oils and pigments. Production of biohydrogen from the leftover biomass. Bioresour Technol 135:128-136. https://doi.org/10.1016/j.biortech. 2012.11.084

Norsker NH, Barbosa MJ, Vermuë MH, Wijffels RH (2011) Microalgal production-a close look at the economics. Biotechnol Adv 29(1):24 27. https://doi.org/10.1016/j.biotechadv.2010.08.005

Phelps CL, Smart NG, Wai CM (1996) Past, present, and possible future applications of supercritical fluid extraction technology. J Chem Educ 73:1163-1168. https://doi.org/10.1021/ed073p1163

Pollet P, Eckertabc CA, Liotta CL (2011) Switchable solvents. Chem Sci 2:609-614. https://doi.org/10.1039/c0sc00568a

Pulz O, Gross W (2004) Valuable products from biotechnology of microalgae. Appl Microbiol Biotechnol 65:635-648. https://doi. org/10.1007/s00253-004-1647-x

Ramos L, Kristenson EM, Brinkman UAT (2002) Current use of pressurised liquid extraction and subcritical water extraction in environmental analysis. J Chromatogr A 975:3-29. https://doi.org/10. 1016/S0021-9673(02)01336-5

Rasouli Z, Valverde-Pérez B, D’Este M, De Francisci D, Angelidaki I (2018) Nutrient recovery from industrial wastewater as single cell protein by a co-culture of green microalgae and methanotrophs. Biochem Eng J 134:129-135. https://doi.org/10.1016/j.bej.2018. 03.010

Rawat I, Kumar RR, Mutanda T, Bux F (2011) Dual role of microalgae: phycoremediation of domestic wastewater and biomass production for sustainable biofuels production. Appl Energy 88:3411-3424. https://doi.org/10.1016/j.apenergy.2010.11.025

Saini RK, Keum Y (2018) Carotenoid extraction methods: a review of recent developments. Food Chem 240:90-103. https://doi.org/10. 1016/j.foodchem.2017.07.099

Samorì C, Lòpez Barreiro D, Vet R, Pezzolesi L, Brilman DWF, Galletti P, Tagliavini E (2013) Effective lipid extraction from algae cultures using switchable solvents. Green Chem 15:353-356. https://doi.org/ $10.1039 / \mathrm{c} 2 \mathrm{gc} 36730 \mathrm{k}$

Sati H, Mitra M, Mishra S, Baredar P (2019) Microalgal lipid extraction strategies for biodiesel production: a review. Algal Res 38:101413. https://doi.org/10.1016/j.algal.2019.101413

Schipper K, Al Muraikhi M, Alghasal GSHS, Saadaoui I, Bounnit T, Rasheed R, Dalgamouni T, Al Jabri HMSJ, Wijffels RH, Barbosa MJ (2019) Potential of novel desert microalgae and cyanobacteria for commercial applications and $\mathrm{CO}_{2}$ sequestration. J Appl Phycol 31:2231-2243. https://doi.org/10.1007/s10811-019-01763-3

Schuur B, Brouwer T, Smink D, Sprakel LMJ (2019) Green solvents for sustainable separation processes. Curr Opin Green Sustain Chem 18:57-65. https://doi.org/10.1016/j.cogsc.2018.12.009

Singh SK, Savoy AW (2020) Ionic liquids synthesis and applications: an overview. J Mol Liq 297:112038. https://doi.org/10.1016/j.molliq. 2019.112038 
Slegers PM, Lösing MB, Wijffels RH, van Straten G, van Boxtel AJB (2013) Scenario evaluation of open pond microalgae production. Algal Res 2:358-368. https://doi.org/10.1016/j.algal.2013.05.001

Souza LS, Simioni C, Bouzon ZL, De Cassia R, Schneider S, Gressler P, Miotto MC, Rossi MJ, Rörig LR (2017) Morphological and ultrastructural characterization of the acidophilic and lipid-producer strain Chlamydomonas acidophila LAFIC-004 (Chlorophyta) under different culture conditions. 1385-1398. https://doi.org/10.1007/ s00709-016-1030-7

Tatke P, Jaiswal Y (2011) An overview of microwave assisted extraction and its applications in herbal drug research. Res J Med Plant 5:2131. https://doi.org/10.3923/rjmp.2011.21.31

Vanderveen JR, Durelle J, Jessop PG (2014) Design and evaluation of switchable-hydrophilicity solvents. Green Chem 16:1187-1197. https://doi.org/10.1039/c3gc42164c

Vega-López S, Kaul N, Devaraj S, Cai RY, German B, Jialal I (2004) Supplementation with $\omega 3$ polyunsaturated fatty acids and all-rac alpha-tocopherol alone and in combination failed to exert an antiinflammatory effect in human volunteers. Metabolism 53:236-240. https://doi.org/10.1016/j.metabol.2003.09.012

Vekariya RL (2017) A review of ionic liquids: applications towards catalytic organic transformations. J Mol Liq 227:44-60. https://doi.org/ 10.1016/j.molliq.2016.11.123

Wang H, Zhang W, Chen L, Wang J, Liu T (2013) The contamination and control of biological pollutants in mass cultivation of microalgae. Bioresour Technol 128:745-750. https://doi.org/10. 1016/j.biortech.2012.10.158

Wang S, Yerkebulan M, Abomohra AEF, El-Khodary S, Wang Q, Souza LS, Simioni C, Bouzon ZL, Schneider RCS, Gressler P, Miotto MC, Rossi MJ, Rörig LR, Schipper K, Al Muraikhi M, Alghasal GSHS, Saadaoui I, Bounnit T, Rasheed R, Dalgamouni T, Al Jabri HMSJ, Wijffels RH, Barbosa MJ, Yusuff AS, Wei L, Huang X, Huang Z (2019) Morphological and ultrastructural characterization of the acidophilic and lipid-producer strain Chlamydomonas acidophila LAFIC-004 (Chlorophyta) under different culture conditions. J Appl Phycol 31:121371-122243. https://doi.org/10.1007/s10811019-01763-3

Wei L, Huang X, Huang Z (2014) Temperature effects on lipid properties of microalgae Tetraselmis subcordiformis and Nannochloropsis oculata as biofuel resources. Chin J Oceanol Limnol 33:99-106. https://doi.org/10.1007/s00343-015-3346-0

Xu L, Wang F, Li HZ, Hu ZM, Guo C, Liu CZ (2010) Development of an efficient electroflocculation technology integrated with dispersed-air flotation for harvesting microalgae. J Chem Technol Biotechnol 85: 1504-1507. https://doi.org/10.1002/jctb.2457

Yin Z, Zhu L, Li S, Hu T, Chu R, Mo F, Hu D, Liu C, Li B (2020) A comprehensive review on cultivation and harvesting of microalgae for biodiesel production: environmental pollution control and future directions. Bioresour Technol 301:122804. https://doi.org/10.1016/ j.biortech.2020.122804

Youn S, Muk J, Keun Y, Oh Y (2017) Cell disruption and lipid extraction for microalgal biorefineries: a review. Bioresour Technol 244:13171328. https://doi.org/10.1016/j.biortech.2017.06.038

Yusuff AS (2019) Environmental effects extraction, optimization, and characterization of oil from green microalgae Chlorophyta species. Energy Sources, Part A Recover Util Environ Eff 1-12 . https://doi. org/10.1080/15567036.2019.1676327

Zghaibi N, Omar R, Kamal SMM, Biak DRA, Harun R (2019) Microwave-assisted brine extraction for enhancement of the quantity and quality of lipid production from microalgae Nannochloropsis sp. Molecules 24:1-21. https://doi.org/10.3390/molecules24193581

Zhang Y, Bakshi BR, Demessie ES (2008) Life cycle assessment of an ionic liquid versus molecular solvents and their applications. Environ Sci Technol 42:1724-1730. https://doi.org/10.1021/ es0713983

Zhang J, Sun Z, Sun P, Chen T, Chen F (2014) Microalgal carotenoids: beneficial effects and potential in human health. Food Funct 5:413425. https://doi.org/10.1039/c3fo60607d

Zhang T, Hu H, Wu Y, Zhuang L, Xu X (2016) Promising solutions to solve the bottlenecks in the large-scale cultivation of microalgae for biomass/bioenergy production. Renew Sust Energ Rev 60:16021614. https://doi.org/10.1016/j.rser.2016.02.008

Zhang R, Parniakov O, Grimi N, Lebovka N, Marchal L, Vorobiev E (2019) Emerging techniques for cell disruption and extraction of valuable bio-molecules of microalgae Nannochloropsis sp. Bioprocess Biosyst Eng 42:173-186. https://doi.org/10.1007/ s00449-018-2038-5

Zheng H, Gao Z, Yin J, Tang X, Ji X, Huang H (2012) Harvesting of microalgae by flocculation with poly (c-glutamic acid). Bioresour Technol 112:212-220. https://doi.org/10.1016/j.biortech.2012.02. 086

Zimmerer J, Pingen D, Hess SK, Koengeter T, Mecking S (2019) microalgae lipids in supercritical carbon dioxide $\uparrow$. Green Chem 21:2428-2435. https://doi.org/10.1039/c9gc00312f

Zullaikah S, P MCJ, Yasmin M, Rachimoellah M, Wu D (2019) Lipids extraction from wet and unbroken microalgae Chlorella vulgaris using subcritical water. Mater Sci Forum 964:103-108. https://doi. org/10.4028/www.scientific.net/MSF.964.103

Publisher's note Springer Nature remains neutral with regard to jurisdictional claims in published maps and institutional affiliations. 